\title{
THE DEVELOPMENT OF MEDIA ACCOUNTING DAKON (DASI) GAME IN ACCOUNTING LEARNING PROCESS TO IMPROVE COGNITIVE, AFFECTIVE, AND PSYCHOMOTORIC ASPECTS OF STUDENTS GRADE XI AT SMK N 2 PURWOREJO
}

\section{PENGEMBANGAN MEDIA PERMAINAN DAKON AKUNTANSI (DASI) DALAM PROSES PEMBELAJARAN AKUNTANSI UNTUK MENINGKATKAN ASPEK KOGNITIF, AFEKTIF, DAN PSIKOMOTORIK SISWA KELAS XI SMK N 2 PURWOREJO}

\author{
Oleh: \\ Maizura Azizah Sekar Ayuningrum \\ Prodi Pendidikan Akuntansi Universitas Negeri Yogyakarta \\ maiimahya@gmail.com \\ $\underline{\text { Sukirno }}$ \\ Staf Pengajar Jurusan Pendidikan Akuntansi Universitas Negeri Yogyakarta
}

\section{Abstrak}

Penelitian ini bertujuan untuk: 1) mengembangkan media permainan dakon Akuntansi untuk membantu meningkatkan aspek kognitif, afektif, dan psikomotorik siswa akuntansi kelas XI AK 4 SMK N 2 Purworejo. 2) mengetahui kelayakan permainan dakon Akuntansi dalam proses pembelajaran siswa akuntansi kelas XI AK 4 SMK N 2 Purworejo. 3) mengetahui respon siswa setelah menggunakan media pembelajaran permainan dakon Akuntansi. Tahapan penelitian dan pengembangan dakon Akuntansi ini terdiri dari empat tahap yaitu: 1) Define atau tahap pendefinisian 2) Design atau tahap perancangan 3) Develop atau tahap pengembangan dan 4) Dessiminate atau tahap penyebaran. Hasil penelitian menunjukkan bahwa dakon Akuntansi sebagai media pembelajaran diperoleh penilaian kategori sangat layak dengan skor rata-rata oleh ahli materi 3,62 oleh ahli media 3,42 dan oleh siswa kelas XI 3,37. Media permainan dakon Akuntansi untuk meningkatkan aspek kognitif, afektif, dan psikomotorik siswa memperoleh hasil yang bervariasi dari setiap aspeknya. Hasil angket dan lembar test siswa pada lembar pre test dan post test menunjukkan bahwa penggunaan media pembelajaran permainan dakon Akuntansi menguatkan aspek kognitif sebesar 0,71; aspek afektif 0,50; dan aspek psikomotorik 0, 70.

Kata kunci: Permainan Dakon, Kognitif, Afektif, Psikomotorik.

\begin{abstract}
This study aims to: 1) development of media Accounting dakon game to improve cognitive, affective, and psychomotoric aspects of students Grade XI AK 4 in SMK N 2 Purworejo. 2) Assess the feasibility of Accounting dakon game in accounting learning process of students Grade XI AK 4 at SMK N 2 Purworejo. 3) Know the students response after using learning media of "DASI" game. Research and development stages on Accounting dakon game consisted of four phases: 1) Defining stage 2) Design stage 3) Development stage, and 4) Disseminate stage. The research results show that Accounting dakon game as a learning media obtained very decent ratings category with an average score of 3.62 by subject matter experts, by media expert of 3.42 and students of Grade XI 3.37. Media of Accounting dakon game to improve cognitive, affective, and psychomotoric aspects of students got various
\end{abstract}


results from every aspects. The questionnaire results and student test work on the pre-test and post-test sheets show that the using media of Accounting dakon game reinforce learning cognitive aspect of 0.71 ; affective aspect of 0.50 ; and psychomotoric aspects 0.70 .

Keywords: Dakon Game, Cognitive, Affective and Psychomotoric.

\section{INTRODUCTION}

Accounting subject is a subject that is considered as the highest level in the field of Social Sciences because it is the most difficult subject of other subjects, according to some comments of accounting students at SMK N 2 Purworejo. Accounting was introduced in depth at the high school level since grade XI. As a student, they thought that accounting could only be obtained once they got theories from teachers. Actually, they unconsciously do financial management since they know numbers and be able to do a small transaction.

Financial accounting in grade XI of accounting program provides students with more theories than practice, so the students are required to memorize or conclude the theories received. The results of observation in the last August provided information about the limitations of the students to concluded materials of accounting, so they tend to memorize them from what are written on the handbook / student modules only.

Before stepping further, it is needed to know the curriculum "Act No. 20 of 2003 about National Education System that the curriculum is a set of plans and arrangements regarding the purpose, content, and teaching materials and methods used to organize learning activities to achieve specific educational objectives". In Curriculum 2013, accounting subject is designed with very simple contents, but the teachers need to be more active and creative to develop materials that are presented neatly in the student handbook. In the students' perception, teachers become greatly affected by the effectiveness of the accounting learning system. Submission and accounting training are essential to be granted and practiced. The level of a study habits is an effort and it is better to be able to help despite few hours of study. (Darwin, 2011).

Gerlach \& Ely states that the media are humans, materials, or events that establish conditions that enable pupils to acquire knowledge, skills, or attitudes (Azhar Arsyad, 2011). Several studies on the development of instructional media as an attempt to improve the quality of education have been a lot made by prospective teachers. So far, significant progress on the development of creativity growth media is visible only in exact sciences such as mathematics, chemistry, biology and physics. Actually, there should be accounting instructional design innovations developed in order to appeal students to gain higher knowledge of financial accounting, such as monopoly, snakes and ladders, and playing cards. Lately, circulation models of accounting pocket comic as a learning media begin. Since the development of learning media, accounting learning should be easier to learn and should attract many students at school.

After I conducted the observations in SMK N 2 Purworejo, I found aspects of learning based on Information and Communication Technology (ICT) that are quite well supported by the fact that each class has LCD projectors, Internet access, as well as access accounting learning to use computers at school computer labs in accounting computer subjects. However it is just about modern learning but I did not find media of traditional game, like monopoly or something like that. Instructional media not only embraces the modern ICT-based learning system, but also still upholds the value of Bhineka Tunggal Ika that one of them is by preserving traditional games. The intention to preserve the value of this traditional game is expected to be parallel 
with cognitive, affective, and psychomotoric learning.

One of observation results obtained are the value of financial accounting subjects which were poor and some students get a scale below the KKM (Kriteria Ketuntasan Minimal). This is evidenced by the values that have been obtained when the daily tests. Teachers complain that less time for students, the free time for holidays and the teacher was unable to attend.

Three aspects of the assessment being focused in Grade XI AK 4 of SMK N 2 Purworejo are cognitive, affective and psychomotoric aspects. Cognitive aspects of students are low and need to be improved, since it is proven that some students do not pass KKM. Besides, the affective aspect takes less role in students especially in the aspect of interest. Aspects of interest in students can be demonstrated by the lack of student response systems in the classroom when the teacher explains simple accounting. Problems on two aspects are ultimately towards the problem of psychomotor aspects in which students respond to less power when the financial accounting learning in class XI AK 4, so it needs some stimulation to improve three aspects.

Accounting Dakon (DASI) is abbreviated with the aim make the students easy to call the name for this new game product. The word of "DASI" have a philosophy about the tie wear by accountants, financial managers and others that expected have the noble values such as philosophy of dakon traditional games that is honest, precise, and generous.

The traditional game of dakon one of the traditional game is still pretty well known by children that they are not too difficult to understand the turnoff the game itself. In philosophy there are benefits of dakon game as calculators that treat the honesty, the intelligence, and the skills of the player, so dakon criteria as a media of learning that can improve cognitive, affective, and psychomotoric aspects of student in the learning process of financial accounting.

Based on the above statement, I gave an overview of the reasons of accounting dakon game development, because the development of traditional learning media is needed to help improve the cognitive, affective, and psychomotoric aspects of students. Cognitive aspects can be served through accounting dakon card which will contain a subject matter which is manifested in a simpler language, so that students are able to conclude independently and do not only depend on textbooks. In affective aspects, students are expected to be able to understand and indirectly implement the 5 (five) indicators of affective aspects through game system specified, while psychomotoric aspects in this game can be observed through the speed of game with predetermined time. Based on the variety of reasons and considerations, then I composed a title "The Development of Media Accounting Dakon (DASI) Game in Accounting Learning Process to Improve Cognitive, Affective, and Psychomotoric Aspects of Students Grade XI at SMK N 2 Purworejo".

\section{RESEARCH METHOD}

This research was a method of Research and Development. According to (Sugiyono, 2012) the research and development methods were used to produce a particular product, test, and the effectiveness of the product.

The research was conducted at SMK Negeri 2 Purworejo located in Semawunggalih, Kutoarjo, Central Java.

This research was counducted by the steps are pre-research step on AugustSeptember 2015. Implementation step on January-February 2016.

The subject of the trial was the students of grade XI AK 4 at SMK N 2 Purworejo in the academic year 2015/2016. The amount of 32 students of Accounting Class.

The research use 4D development model. According Semmel, and Melvyn I. 
Semmel. Ardiansyah, 2012: 14, said there are 4 steps for this development model, they are:

\section{1) Definition Stages}

Analysis of needs at this stage was the media that would be developed by conducting a study of students, classroom teaching, and learning media used. Besides, this stage also conducted an analysis of the syllabus used, analysis of basic competencies, and subject matter. At this stage, the target objects were Accounting students of grade XI at SMK N 2 Purworejo and Accounting teachers involved through observation.

2) Design Stage

At this stage, this design would be a concept system that was tailored to the needs and materials where to be provided by using the card design, manufacturing accounting cards, colouring of dakon, manufactures of regulation play stages and finishing. In this stage, the researcher involved arts of woodcraft designer from Krebet, Bantul.

3) Development Stage

This stage consisted of some expert validation and development test.

a. Expert Validation

Validation was done by subject matter experts, media expert, and accounting teachers of SMK.

b. Development Test

Products which have been declared were feasable to use by the validator to be tested to the students, so the trials carried out in the learning evaluation with the aim for getting an assessment of the accounting dakon by filling in a questionnaire.

4) Dissemination Stage

Dissemination was done by the aim the accounting dakon that was developed for being used by the researchers in the research process where it was able to be useful, widely, and easy for teachers and students in the evaluation process of the interest accounting learning. The dissemination of products made only limited in environments at SMK N 2 Purworejo. Hopefully, it will be needed for further learning. The transfer of the products was able to be done only on a headmaster, curriculum, library, Accounting teachers, and Accounting student of grade XI.

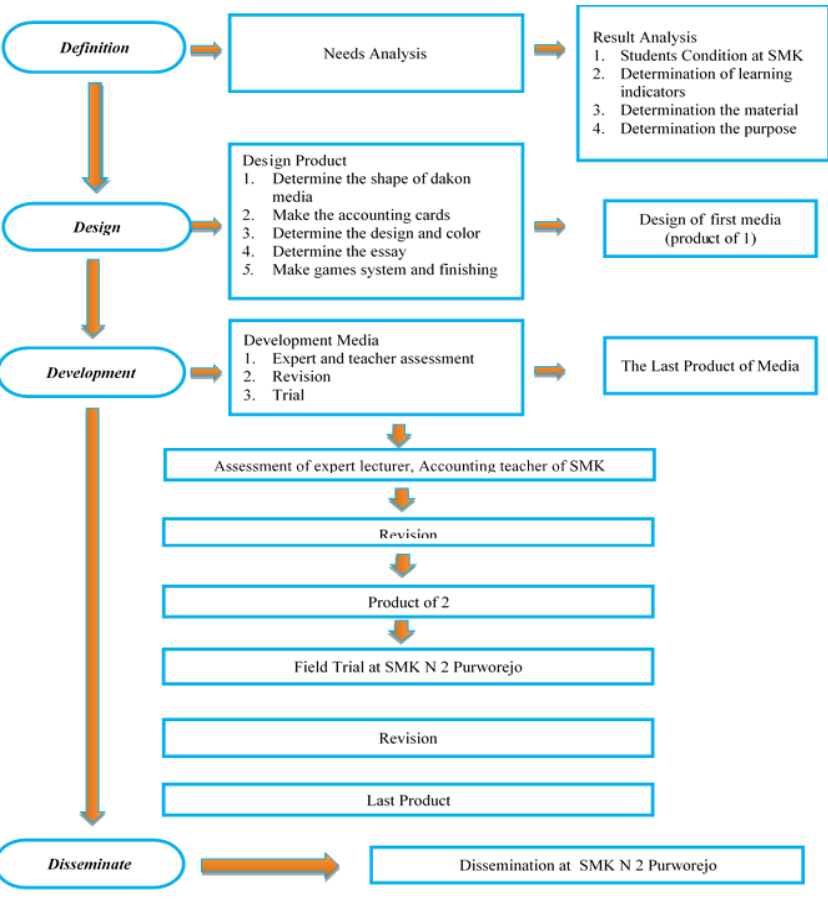

Image 1. Game Stages

The data had been collected to determine the feasibility research and development accounting dakon by using questionnaires and tests that will be given to the subject matter experts, media expert of accounting teachers and students as a test subject. According Sugiyono (2011) questionnaire was a technique of data collection held by giving a set of questions or a written statement to the respondent to answer.

The questionnaire used in this research to collect accounting data regarding the feasibility of dakon given to media experts, subject matter experts, and students. The instrument test was used to measure the basic ability and 
achievement (Suharsimi Arikanto, 2011: 266). Instrument tests intended to measure students' understanding of the materials given.

1) Analysis of Feasibility Data of Learning Media

Table 1. Scoring Each Item

\begin{tabular}{|c|c|c|}
\hline No. & $\begin{array}{c}\text { Choices of the } \\
\text { Answer }\end{array}$ & Score \\
\hline 1. & $\begin{array}{c}\text { Very Valid / Very } \\
\text { Agree }\end{array}$ & 4 \\
\hline 2. & Valid / Agree & 3 \\
\hline 3. & Invalid / Disagree & 2 \\
\hline 4. & $\begin{array}{c}\text { Very Invalid / Very } \\
\text { Disagree (STS) }\end{array}$ & 1 \\
\hline
\end{tabular}

2) Account the average score of the product assessment.

$$
\overline{\mathrm{X}}=\frac{\sum \mathrm{X}}{\mathrm{n}}
$$

Keterangan:

$\overline{\mathrm{X}}=$ the average score

$\sum X=$ total score per grid

$\mathrm{n}=$ total grating

(Eko Putro Widoyoko, 2011: 237)

Table 2. Conversion Formulas Total Mean Score

\begin{tabular}{|c|c|l|}
\hline Category & Formulas & \multicolumn{1}{c|}{ Result } \\
\hline Strongly & $\mathrm{x} \geq \mathrm{Mi}+1,5 \mathrm{SDi}$ & $4>\mathrm{x}>3,25$ \\
\hline Feasible & $\mathrm{Mi}+1,5 \mathrm{SDi}>$ & $3,25>X>2,5$ \\
\hline Unfeasibl & $\mathrm{Mi}>\mathrm{x} \geq \mathrm{Mi}-$ & $2,5>X>1,75$ \\
\hline Strongly & $\mathrm{x} \leq \mathrm{Mi}-1,5$ & $1<X \leq 1,75$ \\
Feasible & SDi & \\
\hline
\end{tabular}

Information:

$\mathrm{X}=$ Score

$\overline{\mathrm{X}} \mathrm{i}=2,5$

$\mathrm{SBi}=0,5$

Source: Zainal Arifin, Unton (1996: 96)

by modification

3) Data of Assessment Cognitive, Affective, and Psychomotoric Students
On student learning outcomes data (pre-test and post-test) would be analyzed using the gain test.

Table 3. Criteria Gain Value

\begin{tabular}{|c|c|}
\hline $\begin{array}{c}\text { Value of Gain } \\
(\mathbf{g})\end{array}$ & Criteria \\
\hline $\mathrm{g}>0.7$ & High \\
\hline $0.7<\mathrm{g}<0.3$ & Middle \\
\hline $\mathrm{g}<0.3$ & Low \\
\hline
\end{tabular}

Source: Hake (2012)

Data analysis techniques gain-test is by calculating the gain $(\mathrm{g})$

$g=\frac{\text { posttest score }- \text { pretest score }}{\text { maximum score }- \text { pretest score }}$

\section{RESULT AND DISCUSSION \\ Research Description}

The research focus is about feasibility of media accounting dakon game (DASI) and improvement of cognitive, affective, and psychomotoric aspects in accounting learning process use financial accounting material of grade XI AK 4 . The research was conducted at SMK Negeri 2 Purworejo located in Semawunggalih, Kutoarjo, Central Java.

The subject of the trial was the students of grade XI AK 4 at SMK N 2 Purworejo in the academic year 2015/2016. The amount of 32 students of Accounting Class.

\section{Result of Research and Development}

a. The implementation of development research was conducted by four stages with the following details: 
1) Defining Stage, the researcher conducted first observations correspondently

2) Design Products Stages, developers designed the design and flow of the "DASI" game based on an analysis need

3) Product Development Stages, researcher ask to the lecturer of Economic Faculty and accounting teacher in SMK N 2 Purworejo to be material expert and media expert give the data validation.

4) Dissemination Stage, purpose of this was to ensure that the media had developed and could be used more widely and evenly.

This is view of Media Accounting Dakon Game.

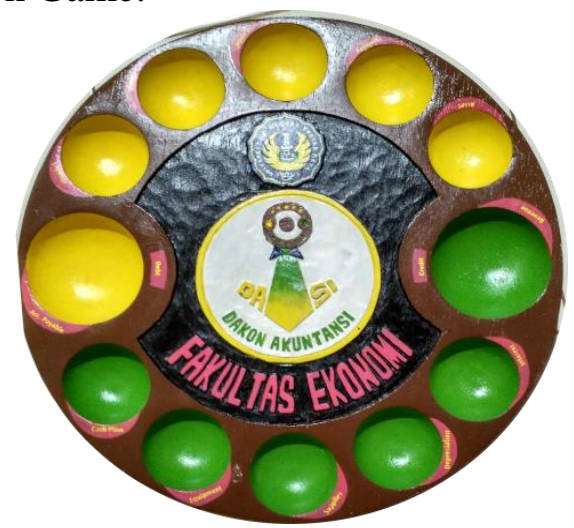

Image 2. Dakon Game

\section{The Feasibility of Media Accounting Dakon Game}

The focus had to know is about development of feasibility media it self. That's way qualitative value of media based on the subject material expert assessment need to show here, included. Feasibility of learning media get from assessment of material subject expert (lecturer of Financial Accounting and teacher of Financial Accounting) and media expert (lecturer of Accounting Learning Media).

\section{1) Material Subject Expert}

Table 4. Analyze of Results Subject Material Expert

\begin{tabular}{|c|l|c|c|}
\hline No & \multicolumn{1}{|c|}{ Aspects } & $\begin{array}{c}\text { Average } \\
\text { Value }\end{array}$ & $\begin{array}{c}\text { Qualitative } \\
\text { Value }\end{array}$ \\
\hline 1 & $\begin{array}{l}\text { Quality of } \\
\text { material }\end{array}$ & 3.57 & $\mathrm{~A}$ \\
\hline 2 & Advantages & 3.67 & $\mathrm{~A}$ \\
\hline $\begin{array}{l}\text { Average Total } \\
\text { Average }\end{array}$ & 7.24 & $\mathrm{~A}$ \\
\hline $\begin{array}{l}\text { Average Score } \\
\text { per Aspects }\end{array}$ & 3.62 & $\mathrm{~A}$ \\
\hline
\end{tabular}

According to the table 4, a feasibility assessment of subject material experts knew that "DASI" developed in terms of the feasibility of the material by subject matter experts obtained a total average score of 3.62. Based on the conversion table about ideal criteria assessment, it was known that the average score of each aspect of 3.62 in the interval score $4>x \geq$ 3.25 , which meaning that the assessment of subject material expert on feasibility of material got value "A" in the category of " Strongly Feasible".

\section{2) Media Expert}

Table 2. Analysis Results of Validation on Media Experts

\begin{tabular}{|c|l|c|c|}
\hline No & \multicolumn{1}{|c|}{ Aspects } & $\begin{array}{c}\text { Average } \\
\text { Value }\end{array}$ & $\begin{array}{c}\text { Qualitative } \\
\text { Value }\end{array}$ \\
\hline 1 & $\begin{array}{l}\text { Design of } \\
\text { Dakon Game }\end{array}$ & 3.50 & $\mathrm{~A}$ \\
\hline 2 & $\begin{array}{l}\text { Designs of } \\
\text { Dakon Card }\end{array}$ & 3.33 & $\mathrm{~A}$ \\
\hline 3 & $\begin{array}{l}\text { Game } \\
\text { Guidebook }\end{array}$ & 3.43 & $\mathrm{~A}$ \\
\hline \multicolumn{2}{|c|}{$\begin{array}{c}\text { Average Total } \\
\text { Score }\end{array}$} & 10.25 & $\mathrm{~A}$ \\
\hline $\begin{array}{c}\text { Average Score per } \\
\text { Aspects }\end{array}$ & 3.42 & $\mathrm{~A}$ \\
\hline
\end{tabular}

According to the table 5, media feasibility assessment was known that "DASI" which developed in terms of media feasibility by media experts which obtained a total average score of each aspect of 3.42. Based on the conversion 
table of criteria ideal assessment, it was known that the average score of 3.42 in the interval score $4>x \geq 3.25$ which meaning the media expert assessment on the feasibility of product got value "A" in the category of "Strongly Feasible".

\section{Analysis of Results of Testing in Vocational Students}

Trial on Vocational Students performed to determine the response of students related learning media of "DASI" traditional game which being used by students as a media of accounting learning support especially on material financial accounting inventory. At this stage, the researcher devided into 4 (four) stages. Observing, going to the classroom for 2 hours, 15 minutes to validate media to the students, and giving students the opportunity to play "DASI" to take the aspects of students psychomotoric data.

Table 6. Results Analysis of Trial Testing Students

\begin{tabular}{|c|c|c|c|}
\hline No & Aspects & $\begin{array}{c}\text { Average } \\
\text { Value }\end{array}$ & $\begin{array}{c}\text { Qualitative } \\
\text { Value }\end{array}$ \\
\hline 1 & Presentation & 3.34 & $\mathrm{~A}$ \\
\hline 2 & Advantages & 3.40 & $\mathrm{~A}$ \\
\hline $\begin{array}{c}\text { Average Total } \\
\text { Score }\end{array}$ & 6.74 & $\mathrm{~A}$ \\
\hline \multicolumn{2}{|c|}{$\begin{array}{c}\text { Average Score } \\
\text { per Aspects }\end{array}$} & 3.37 & $\mathrm{~A}$ \\
\hline
\end{tabular}

According to the table 5 and 6 , the product feasibility assessment was known that "DASI" which having developed in terms of the test results by students had obtained an average total of score in each aspect of 3.37. Based on the table 23 of ideal assessment criteria had beed known that the average score of 3.37 in the interval score 4 $>\mathrm{x} \geq 3.25$, it meant the assessment from trial test students on the product feasibility gets value "A" in the category of "Strongly Feasible".

\section{Improvement of Learning Outcomes Aspects}

This aspect was examined to determine assessment of increase students' understanding on cognitive, affective, and psychomotoric aspects through the media developed. The students' assessment results of these aspects obtained through the gain (g) on a pretest and posttest questionnaire as follows:

Table 7. Data of Gain Average on Cognitive, Affective, and Psychomotoric Aspects Students

\begin{tabular}{|c|l|c|c|c|}
\hline $\begin{array}{c}\text { No } \\
\cdot\end{array}$ & Aspects & $\begin{array}{c}\text { Pre Test } \\
\text { Average }\end{array}$ & $\begin{array}{c}\text { Post } \\
\text { Test } \\
\text { Average }\end{array}$ & $\begin{array}{c}\text { Gain } \\
\text { (g) }\end{array}$ \\
\hline 1. & Cognitive & 64 & 89 & 0.7 \\
\hline 2. & Affective & 27 & 33 & 0.5 \\
\hline 3. & $\begin{array}{l}\text { Psychom } \\
\text { otoric }\end{array}$ & 15 & 21 & 0.7 \\
\hline
\end{tabular}

Based on the table 7, it could be seen about an average of the increasingvalue in cognitive, affective, and psychomotoric aspects through value standard gain $(\mathrm{g})$ in which an average of increasing in cognitive aspect of student is 0.7 or $70 \%$, with a minimum standard the value gain 0,5 and a maximum standard the value gain 0,9 .

Affective aspect through value standard gain $(\mathrm{g})$ in which an average of increasing in affective aspect of student is 0.5 or $50 \%$, with a minimum standard the value gain 0,3 and a maximum standard the value gain 0.8. Psychomotoric aspect through value standard gain $(\mathrm{g})$ in which an average of increasing in cognitive aspect of student is 0.7 or $70 \%$, with a minimum standard the value gain 0.3 and a maximum standard the value gain 0.9 .

Interpretation of the data result above showed the cognitive aspect could be known that students were having a high strengthening, in affective aspect students also had an intermediate strengthening, in psychomotoric aspect students had a high strengthening in which all of strengthening 
occured after using learning media of traditional game dakon accounting.

\section{CONCLUSIONS AND SUGGESTION}

\section{Conclusions}

Based on the research and discussion, it can be concluded that:

a. The development of Accounting learning media shaped "DASI" in inventory financial accounting material for SMK used as interest learning media to improve learning outcomes of the students, they were cognitive, affective, and psychomotoric aspects through four stages: defining, designing, developing, and disseminating.

b. From the development result of learning media "DASI" or game could improve the aspects of cognitive, affective, and psychomotoric categorized as very feasible with the average score given by subject matter experts of 3,62 by category of very feasible, media expert 3.42 by the category. This method "DASI" was very feasible. Further more its media of "DASI" game can be used in Accounting learning of inventory material.

c. Media of "DASI" game was capable to be used as a way of improving cognitive, affective, and psychomotoric aspects of students. It can be seen from the value of gain $(\mathrm{g})$ each the aspects, students had started to appear even though the strengthening that occuring varies. Learning media of "DASI" can strengthen those aspects of learning outcomes which existing on students by categories:

1) Cognitive development tests increased to be $20 \%$ with a gain standard of 0.71 as high reinforcement category

2) Affective on the test development increased to be $16 \%$ with a gain standard of
0.50. it was the moderate reinforcement category

3) Psychomotoric on test development increased to be $21 \%$ with a gain standard of 0.66 . So, it became the moderate reinforcement category

\section{Suggestion}

Based on the results of the research, suggested the following things:

a. In the cognitive aspect, the students who get a low score can be assisted with the addition time to read the accounting material card and the teacher gave the conclusion at the end of the session, while students who get the highest score advised to share knowledge of material card which being read to friends who get low scores.

b. On the affective aspects, students who get low scores can be stimulated using more interesting game guide books and there are penalty points for the player who entered the seed to the wrong barn to train students to be more careful and disciplined in every action.

c. In the psychomotoric aspects, students who get low scores should be supported with the limited time over more narrow starts from the beginning of the game until the end to make students more active and look vibrant.

d. Research and development need to do sustainable with the presence of some teachers directly in order to be able to give the advices noticeable improvement over so the other accounting teachers are able to utilize this learning media.

e. Researcher need for a validation test the material better to minimize the errors of the material summary and linguist experts to produce game guidebook and to make it better.

f. On the feasibility aspects of media appears to be lower on dakon seeds in order to be replaced with a much 
heavier and larger that are not easily lost.

\section{REFERENCES}

Anik, Ghufron, dkk. (2007). Panduan Penelitian dan Pengembangan Bidang Pendidikan dan Pembelajaran. Yogyakarta: Lembaga Penelitian Universitas Negeri Yogyakarta.

Azhar, Arsyad. (2011). Media Pembelajaran. Jakarta: PT Raja Grafindo Persada.

Eko Putro Widoyoko. (2011). Evaluasi Program Pembelajaran. Yogyakarta: Pustaka Pelajar.

Hake, Richard. (2012. Analyzing Change/Gain Score. USA: Indiana University.

Sugiyono. (2013). Metode Penelitian Kuantitatif Kualitatif dan $R \& D$. Bandung: Alfabeta.

Suharsimi Arikunto. (2010) Prosedur Penelitian Suatu Pendekatan Praktik. Jakarta: Rineka Cipta.

YU,D., Darwin. (2011). How Much Do Study Habits, Skills, and Attitudes Affect Student. New Horizons in Education : 1 .

Zainal Arifin. (2011). Penelitian Pendidikan Bandung: PT. Remaja Rosdakarya. 